\title{
Bacteria causing symptomatic urinary tract infection or asymptomatic bacteriuria
}

\author{
A. P. ROBERTS AND RUTH PHILLIPS \\ From the Department of Medicine, Charing Cross Hospital Medical School, London W6 8RF, UK
}

SUMMARY One thousand bacterial isolates from consecutive suprapubic aspirations of urine in two groups of patients with symptomatic urinary tract infection and two groups with asymptomatic bacteriuria were studied.

Staphylococci accounted for 13 and $27 \%$ of the isolates from symptomatic patients but for only 3 and $4 \%$ of strains from asymptomatic bacteriuria. Conversely, 18 and $30 \%$ of Escherichia coli isolates from asymptomatic bacteriuria were auto-agglutinable when tested with antisera to the common urinary O-serogroups, whereas such strains accounted for only 5 and $7 \%$ of the $E$. coli from symptomatic patients. The high prevalence of auto-agglutinable $E$. coli in asymptomatic bacteriuria was accompanied by a reduction in the frequency of the common urinary $\mathrm{O}$-serogroups rather than other smooth strains.

We have previously reported a high prevalence of coagulase-negative staphylococci in two groups of patients with symptomatic urinary tract infection (Bailey et al., 1971; Dove et al., 1972) but found only a low prevalence of such organisms when screening for asymptomatic bacteriuria in non-pregnant women (Gower and Roberts, 1975). In a study of Escherichia coli isolates from schoolgirls (Olling et al., 1973), it was found that the seven O-serogroups most commonly associated with symptomatic infections were much less frequent in asymptomatic bacteriuria and appeared to be replaced by autoagglutinable strains. More recently (Roberts et al., 1975), we have presented evidence that, unlike the situation in pregnancy, in the non-pregnant woman symptomatic infections rarely arise from preexisting asymptomatic bacteriuria.

These findings raise the question of the relative importance of bacterial and host factors in determining whether or not symptoms occur in the presence of bacteriuria. In this report 1000 isolates, from consecutive suprapubic aspirates of urine, are reviewed with regard to the symptomatic status of the patient.

\section{Patients and methods}

Four groups of patients were included in the study. Patients attending the urinary infection clinics at

Received for publication 8 November 1978
Charing Cross Hospital were divided into those presenting with symptoms of urinary tract infection and those in whom asymptomatic bacteriuria was detected at a routine follow-up visit. Symptomatic patients presenting at a local general practice and patients found to have asymptomatic bacteriuria in a screening programme at well-woman clinics (cervical smear screening and family planning clinics) were also included. The patients were all women between the ages of 16 and 65 , and none was pregnant at the time the infection was detected.

In patients presenting with symptoms suggestive of urinary tract infection, suprapubic aspiration of urine was carried out as described by Beard et al. (1965). Midstream specimens of urine were collected initially from all asymptomatic patients. These patients were recalled for suprapubic aspiration of urine if the midstream specimen showed a growth of Gram-negative bacilli either in pure culture or as the predominant organism in a mixed culture, a pure growth of Gram-positive cocci, or a mixed growth in which Gram-positive cocci predominated provided the viable count was greater than $10^{4}$ per millilitre.

All specimens were plated on to blood agar and MacConkey agar, and the viable count was estimated by the filter-paper strip method (Leigh and Williams, 1964) using CLED medium (Oxoid Ltd); the reliability of this method in our laboratory has been reported previously (Gower and Roberts, 1975). Unless differences in colonial morphology indicated 
the presence of more than one bacterial genus, a single colony was selected from the culture of each infected suprapubic aspirate for further identification. The isolates were identified using standard methods (Cowan and Steel, 1965; Cowan, 1974) but, for convenience in presenting the results, Gramnegative bacilli were grouped as Escherichia (including lactose-negative, anaerogenic, or non-motile strains), proteus (including indole-positive strains), klebsiella and 'other Gram-negative bacilli'; Grampositive cocci were grouped as staphyloccocus if catalase-positive and as streptococcus if catalasenegative.

Isolates identified as Escherichia were grouped using antisera against serogroups 01, 02, 04, 06, 07, 09, 011, 018, and 075; the sera all reacted at titres of 1 in 1280 or greater with the homologous organism, and none showed heterologous reactions at titres of 1 in 1000 or greater. For the purposes of this study, isolates that failed to agglutinate in any of the sera were referred to as non-typable and those that agglutinated in all sera and in saline alone were designated auto-agglutinable. Isolates belonging to the listed O-sera groups were collectively referred to as typable.

Organisms identified as staphylococcus were grouped according to the classification of BairdParker (1963) with the limited range of tests used previously (Roberts, 1967).

\section{Results}

Of the 1000 organisms, 767 were isolated from patients attending the hospital urinary infection clinics-577 from symptomatic patients and 190 from asymptomatic patients. Symptomatic patients presenting in general practice accounted for 128 isolates, and 105 were from asymptomatic patients attending well-woman clinics. The genera of the isolates from each group of patients are shown in Table 1. The major differences found were the increased prevalence of staphylococcus isolates and a corresponding decrease in Escherichia strains in the two symptomatic groups compared with the two asymptomatic groups.

When the staphylococcus isolates were classified according to Baird-Parker (1963) all but eight of them were found to be micrococci of subgroup 3 . Of the eight staphylococci, one, isolated from a hospital symptomatic patient, was coagulase-positive while the remaining seven, four from hospital symptomatic patients, two from hospital asymptomatic patients, and one from general practice, were coagulase-negative.

The prevalence of the various serogroups of $E$. coli is shown for each of the four groups of patients in Table 2. The main differences found were the high prevalence of auto-agglutinable isolates from each of the asymptomatic groups compared with the two symptomatic groups. In the asymptomatic patients from well-woman clinics the very high prevalence of auto-agglutinable isolates $(30 \%)$ appeared to be related to a reduced prevalence of typable isolates compared with either of the symptomatic groups. A reduced prevalence of typable isolates accounted for most of the increased prevalence of auto-agglutinable organisms in the hospital asymptomatic patients, but in this group there was also a reduction in the proportion of non-typable isolates compared with the other groups.

As the number of isolates in most of the O-serogroups was too low for valid statistical comparison in $4 \times 2$ contingency tables, the isolates from both symptomatic groups were combined and compared with those from all asymptomatic patients (Table 3); numbers for six of the nine $\mathrm{O}$-serogroups were then

Table 1 Genera of 1000 organisms isolated by suprapubic aspiration of urine in two groups of women with symptomatic urinary tract infection and two groups with asymptomatic bacteriuria

\begin{tabular}{|c|c|c|c|c|c|c|c|c|c|c|}
\hline \multirow[t]{4}{*}{ Genus } & \multicolumn{8}{|c|}{ Source of organisms } & \multirow[t]{4}{*}{$x^{2 *}$} & \multirow[t]{4}{*}{$\mathbf{P}$} \\
\hline & \multicolumn{4}{|c|}{ Hospital urinary infection clinic } & \multirow{2}{*}{\multicolumn{2}{|c|}{$\frac{\text { General practice }}{\text { Symptomatic }}$}} & \multirow{2}{*}{\multicolumn{2}{|c|}{$\frac{\text { Well-woman clinic }}{\text { Asymptomatic }}$}} & & \\
\hline & \multicolumn{2}{|c|}{ Symptomatic } & \multicolumn{2}{|c|}{ Asymptomatic } & & & & & & \\
\hline & No. & $\%$ & No. & $\%$ & No. & $\%$ & No. & $\%$ & & \\
\hline Escherichia & 406 & 70 & 155 & 82 & 81 & 63 & 89 & 85 & $22 \cdot 681$ & $<0.001$ \\
\hline Staphylococcus & 77 & 13 & 5 & 3 & 34 & 27 & 4 & 4 & $49 \cdot 155$ & $<0.001$ \\
\hline Proteus & 50 & 9 & 13 & 7 & 9 & 7 & 6 & 6 & $1 \cdot 584$ & $>0.4$ \\
\hline Klebsiella & 21 & 4 & 9 & 5 & 3 & 2 & 5 & 5 & 1.505 & $>0.4$ \\
\hline Streptococcus & 15 & 3 & 7 & 4 & 1 & $<1$ & 1 & $<1$ & NV & \\
\hline Other Gram-negative bacilli & 8 & 1 & 1 & $<1$ & $\mathbf{0}$ & & $\mathbf{0}$ & & NV & \\
\hline Total & 577 & & 190 & & 128 & & 105 & & & \\
\hline
\end{tabular}

*Each genus compared with the remainder in $4 \times 2$ contingency tables. $\mathrm{NV}=\chi^{2}$ not valid with these numbers. 
Table 2 Serogroups of Escherichia coli isolated by suprapubic aspiration of urine in two groups of women with symptomatic urinary tract infection and two groups with asymptomatic bacteriuria

\begin{tabular}{|c|c|c|c|c|c|c|c|c|c|c|}
\hline \multirow[t]{4}{*}{ Serogroup } & \multicolumn{8}{|c|}{ Source of organisms } & \multirow[t]{4}{*}{$\chi^{2 *}$} & \multirow[t]{4}{*}{$\mathbf{P}$} \\
\hline & \multicolumn{4}{|c|}{ Hospital urinary infection clinic } & \multirow{2}{*}{\multicolumn{2}{|c|}{$\frac{\text { General practice }}{\text { Symptomatic }}$}} & \multirow{2}{*}{\multicolumn{2}{|c|}{$\frac{\text { Well-woman clinic }}{\text { Asymptomatic }}$}} & & \\
\hline & \multicolumn{2}{|c|}{ Symptomatic } & \multicolumn{2}{|c|}{ Asymptomatic } & & & & & & \\
\hline & No. & $\%$ & No. & $\%$ & No. & $\%$ & No. & $\%$ & & \\
\hline 01 & 28 & 7 & 13 & 8 & 7 & 9 & 4 & 5 & $1 \cdot 620$ & $>0.4$ \\
\hline 02 & 4 & $<1$ & 6 & 4 & 2 & 3 & 1 & 1 & NV & \\
\hline 04 & 25 & 6 & 5 & 3 & 3 & 4 & 1 & 1 & NV & \\
\hline 06 & 46 & 11 & 9 & 6 & 9 & 11 & 7 & 8 & $4 \cdot 435$ & $>0.1$ \\
\hline 07 & 14 & 3 & 4 & 3 & 1 & 1 & 0 & & NV & \\
\hline 09 & 7 & 2 & 6 & 4 & 1 & 1 & 0 & & NV & \\
\hline 011 & 2 & $<1$ & 0 & & 2 & 2 & 0 & & NV & \\
\hline 018 & 24 & 6 & 6 & 4 & 7 & 9 & 2 & 2 & NV & \\
\hline 075 & 37 & 9 & 11 & 7 & 7 & 9 & 5 & 6 & $1 \cdot 508$ & $>0.4$ \\
\hline Typable & 187 & 46 & 60 & 39 & 39 & 48 & 20 & 22 & $18 \cdot 636$ & $<0.001$ \\
\hline Non-typable & 190 & 47 & 67 & 43 & 38 & 47 & 42 & 47 & 0.659 & $>0.7$ \\
\hline AA & 29 & 7 & 28 & 18 & 4 & 5 & 27 & 30 & $46 \cdot 504$ & $<0.001$ \\
\hline Total & 406 & & 155 & & 81 & & 89 & & & \\
\hline
\end{tabular}

*Each group compared with the remainder in $4 \times 2$ contingency tables.

$\mathrm{NV}=\chi^{2}$ not valid with these numbers.

AA $=$ Auto-agglutinable.

Table 3 Serogroups of Escherichia coli isolated by suprapubic aspiration of urine in all patients with symptoms compared with those isolated from all patients with asymptomatic bacteriuria

\begin{tabular}{|c|c|c|c|c|c|c|}
\hline \multirow[t]{3}{*}{ Serogroup } & \multicolumn{4}{|c|}{$\begin{array}{l}\text { Source of organisms: } \\
\text { All patients with Escherichia } \\
\text { coli infections }\end{array}$} & \multirow[t]{3}{*}{$x^{2 *}$} & \multirow[t]{3}{*}{$\mathbf{P}$} \\
\hline & \multicolumn{2}{|c|}{ Symptomatic } & \multicolumn{2}{|c|}{ Asymptomatic } & & \\
\hline & No. & $\%$ & No. & $\%$ & & \\
\hline 01 & 35 & 7 & 17 & 7 & 0.002 & $>0.9$ \\
\hline 02 & 6 & 1 & 7 & 3 & NV & \\
\hline 04 & 28 & 6 & 6 & 2 & $3 \cdot 261$ & $>0.05$ \\
\hline 06 & 55 & 11 & 16 & 7 & 3.636 & $>0.05$ \\
\hline 07 & 15 & 3 & 4 & 2 & 0.824 & $>0.3$ \\
\hline 09 & 8 & 2 & 6 & 2 & NV & \\
\hline 011 & 4 & $<1$ & 0 & & NV & \\
\hline 018 & 31 & 6 & 8 & 3 & $2 \cdot 486$ & $>0 \cdot 1$ \\
\hline 075 & 44 & 9 & 16 & 7 & 1.016 & $>0 \cdot 3$ \\
\hline Typable & 226 & 46 & 80 & 33 & $11 \cdot 836$ & $<0.001$ \\
\hline Non-typable & 228 & 47 & 109 & 45 & 0.221 & $>0.6$ \\
\hline AA & 33 & 7 & 55 & 22 & $36 \cdot 678$ & $<0.001$ \\
\hline Total & 487 & & 244 & & & \\
\hline
\end{tabular}

*Each group compared with the remainder in $2 \times 2$ contingency tables with Yates' correction.

$\mathrm{NV}=\chi^{2}$ not valid with these numbers

AA $=$ Auto-agglutinable.

sufficient for valid comparison. Although three O-serogroups, 04, 06, and 018, appeared to be more common in symptomatic infections than in asymptomatic bacteriuria none of the differences reached a conventional level of statistical significance.

The 1000 isolates included in the study were derived from 974 suprapubic aspirates, $26(2 \cdot 7 \%)$ of which contained two bacterial genera; none contained more than two. The combination Escherichia/staphylococcus accounted for 13 of the 26 specimens while none of the other combinations was found in more than three specimens (Table 4). The prevalence of 'mixed' cultures ranged from $2 \cdot 0$ to $3.2 \%$ in the four groups of patients but the

Table 4 Suprapubic aspirates of urine from which more than one genus of bacteria was identified

\begin{tabular}{|c|c|c|c|c|}
\hline \multirow[t]{3}{*}{ Genus } & \multicolumn{4}{|c|}{ Source of specimens } \\
\hline & \multicolumn{2}{|c|}{$\begin{array}{l}\text { Hospital urinary } \\
\text { infection clinic }\end{array}$} & \multirow{2}{*}{$\begin{array}{l}\text { General } \\
\text { practice } \\
\\
\text { Sympto- } \\
\text { matic } \\
(\text { No. })\end{array}$} & \multirow{2}{*}{$\begin{array}{l}\text { Well-woman } \\
\text { clinic } \\
\text { Asympto- } \\
\text { matic } \\
(\text { No. })\end{array}$} \\
\hline & $\begin{array}{l}\text { Sympto- } \\
\text { matic } \\
\text { (No.) }\end{array}$ & $\begin{array}{l}\text { Asympto- } \\
\text { matic } \\
\text { (No.) }\end{array}$ & & \\
\hline $\begin{array}{l}\text { Escherichia/ } \\
\text { S }\end{array}$ & 8 & 1 & 3 & 1 \\
\hline Escherichia/ & & & & \\
\hline $\begin{array}{r}\text { Klebsiella } \\
\text { Escherichia/ }\end{array}$ & 1 & 1 & 1 & 0 \\
\hline $\begin{array}{l}\text { Escherichia/ } \\
\text { Proteus }\end{array}$ & 1 & 1 & 0 & 0 \\
\hline Escherichia/ & & & & \\
\hline $\begin{array}{l}\text { Streptococcus } \\
\text { Staphylococcus/ }\end{array}$ & 0 & 1 & 0 & 1 \\
\hline $\begin{array}{l}\text { Proteus } \\
\text { Staphylococcus/ }\end{array}$ & 2 & 1 & 0 & \\
\hline $\begin{array}{l}\text { Staphylococcus/ } \\
\text { Klebsiella }\end{array}$ & 1 & 0 & 0 & 0 \\
\hline $\begin{array}{l}\text { Pseudomonas/ } \\
\text { Klebsiella } \\
\text { Pseudomonas/ }\end{array}$ & 1 & 0 & 0 & 0 \\
\hline $\begin{array}{l}\text { Pseudomonas/ } \\
\text { Streptococcus }\end{array}$ & 1 & 0 & 0 & 0 \\
\hline Total & 15 & 5 & 4 & 2 \\
\hline
\end{tabular}


numbers were too small for valid statistical comparison.

\section{Discussion}

Although each bacterial genus occurred in both symptomatic infections and asymptomatic bacteriuria it is clear that, in these non-pregnant women, coagulase-negative staphylococci are rarely responsible for infection without causing symptoms. In a review of urinary tract infection due to coagulasenegative staphylococci, Maskell (1974) drew attention to the high frequency of micrococcal infections in studies of symptomatic patients compared with that found in studies in which patients were screened for asymptomatic bacteriuria. Such comparisons might be considered invalid, however, due to differences in technique, media, and the significance attached to such organisms by various laboratories. It could be argued that in the present study significant numbers of staphylococcal infections were wrongly excluded by the initial midstream urine in the asymptomatic groups. However, with the qualitative and quantitative criteria used, this is likely only if the viable count in the bladder urine is less than $10^{4} \mathrm{ml}^{-1}$; only $12(16 \%)$ of the 77 staphylococci from the hospital symptomatic patients and $8(24 \%)$ of the 34 such organisms from the general practice patients came from specimens with a viable count less than $10^{4} \mathrm{ml}^{-1}$. Assuming a similar proportion of low counts in the asymptomatic patients, the numbers with staphylococci might be increased by a maximum of $30 \%$, giving a prevalence of less than $6 \%$, which is still significantly less than the 13 and $27 \%$ prevalence in the symptomatic groups. Any Gramnegative infections similarly excluded in error would tend to restore the lower prevalence of staphylococcal infections although such errors are less likely to occur due to the different criteria used.

The $2 \cdot 0-3 \cdot 2 \%$ prevalence of infections involving two bacterial genera in the present study was lower than the $5 \%$ reported by Stamey et al. (1965) in a previous large study of suprapubic aspirations. However, their patients were attending a specialised urological clinic, and it was found that 'mixed' infections were almost invariably associated with gross abnormalities of the urinary tract; it is possible that such abnormalities were less frequent among our patients. That the most common combination of genera was Escherichia/staphylococcus is not surprising as these were the most common genera overall.

The only significant differences found among the $E$. coli isolates were the high prevalence of autoagglutinable strains in the asymptomatic groups compared with those having symptomatic infections; similar differences have been reported from studies in schoolgirls (Olling et al., 1973; Lindberg et al., 1975). In the latter study it was suggested that lipopolysaccharides are probably responsible for most of the symptoms of the host. This appears unlikely as strains of the same O-serogroup, and therefore of similar lipopolysaccharide composition, are found in both symptomatic and asymptomatic patients. Furthermore, auto-agglutinable isolates, deficient in lipopolysaccharide $\mathrm{O}$-specific side chains, although much more frequent in asymptomatic bacteriuria are also found in some symptomatic patients. We have previously presented evidence (Roberts et al., 1975) that if symptoms are to occur in non-pregnant women, they do so in most cases within a short time of the infection becoming established, whereas in most cases of asymptomatic bacteriuria infection has been present for some considerable time when detected by chance in a screening programme or at a routine visit to a follow-up clinic. This suggests a possible explanation for the high prevalence of autoagglutinable strains in asymptomatic bacteriuria as the classical method of obtaining rough mutants is to subculture aged broth cultures of smooth strains. Any loss of ability to synthesise $\mathrm{O}$-specific side chains is likely to result in a faster rate of growth which will have a selective advantage in the urinary tract (Dugdale, 1969), and auto-agglutinable mutants will replace the original smooth strain. Such changes were in fact reported by Lindberg et al. (1975) in two schoolgirls with untreated asymptomatic bacteriuria followed for 12-15 months.

In agreement with Lindberg et al. (1975) we have found that the high frequency of auto-agglutinable strains in asymptomatic bacteriuria is largely at the expense of the more common urinary $\mathrm{O}$-serogroups. If the above explanation for the high prevalence of auto-agglutinable strains is correct, this must indicate either that the common O-groups more readily undergo mutation to auto-agglutination or that they are initially much more frequent than other O-groups in asymptomatic bacteriuria.

There is increasing realisation that the main problem with urinary tract infection, at least in adults, is not the prevention of chronic renal failure but rather the morbidity associated with recurrent attacks of symptoms. This emphasises the importance of determining the factors responsible for symptoms and, in particular, whether these are host or bacterial factors or a combination of both. The differences in the distribution of various bacteria between symptomatic and asymptomatic patients in this study indicate that the presence or absence of symptoms is not solely determined by host factors. If we could define the bacterial factors responsible for symptoms and any host conditions necessary for 
their production we would have two further approaches to the prevention of recurrent symptomatic urinary tract infection.

The $E$. coli O-antisera used in this study were prepared and supplied by the Biological Reagents Section, Center for Disease Control, Atlanta, Ga, USA.

\section{References}

Bailey, R. R., Roberts, A. P., Gower, P. E., and de Wardener, H. E. (1971). Prevention of urinary-tract infection with low-dose nitrofurantoin. Lancet, 2, 1112-1114.

Baird-Parker, A. C. (1963). A classification of micrococci and staphylococci based on physiological and biochemical tests. Journal of General Microbiology, 30, 409-427.

Beard, R. W., McCoy, D. R., Newton, J. R., and Clayton, S. G. (1965). Diagnosis of urinary infection by suprapubic bladder puncture. Lancet, 2, 610-611.

Cowan, S. T. (1974). Cowan and Steel's Manual for the Identification of Medical Bacteria, 2nd edition. Cambridge University Press, Cambridge.

Cowan, S. T., and Steel, K. J. (1965). Manual for the Identification of Medical Bacteria. Cambridge University Press, Cambridge.

Dove, G. A., Bailey, A. J., Gower, P. E., Roberts, A. P., and de Wardener, H. E. (1972). Diagnosis of urinarytract infection in general practice. Lancet, 2, 1281-1283.

Dugdale, A. E. (1969). The defenses of the urinary tract against infection. A mathematical model. Investigative Urology, 6, 371-382.
Gower, P. E., and Roberts, A. P. (1975). Qualitative assessment of midstream urine cultures in the detection of bacteriuria. Clinical Nephrology, 3, 10-13.

Leigh, D. A., and Williams, J. D. (1964). Method for the detection of significant bacteriuria in large groups of patients. Journal of Clinical Pathology, 17, 498-503.

Lindberg, U., Hanson, L. Å., Jodal, U., Lidin-Janson, G., Lincoln, K., and Olling, S. (1975). Asymptomatic bacteriuria in schoolgirls. II. Differences in Escherichia coli causing asymptomatic and symptomatic bacteriuria. Acta Paediatrica Scandinavica, 64, 432-436.

Maskell, R. (1974). Importance of coagulase-negative staphylococci as pathogens in the urinary tract. Lancet, 1, 1155-1158.

Olling, S., Hanson, L. Å., Holmgren, J., Jodal, U., Lincoln, K., and Lindberg, U. (1973). The bactericidal effect of normal human serum on $E$. coli strains from normals and from patients with urinary tract infections. Infection, 1, 24-28.

Roberts, A. P. (1967). Micrococcaceae from the urinary tract in pregnancy. Journal of Clinical Pathology, 20, 631-632.

Roberts, A. P., Linton. J. D., Waterman, A. M., Gower, P. E., and Koutsaimanis, K. G. (1975). Urinary and faecal Escherichia coli O-serogroups in symptomatic urinary-tract infection and asymptomatic bacteriuria. Journal of Medical Microbiology, 8, 311-318.

Stamey, T. A., Govan. D. E., and Palmer, J. M. (1965). The localization and treatment of urinary tract infections: the role of bactericidal urine levels as opposed to serum levels. Medicine, 44, 1-36.

Requests for reprints to: Dr A. P. Roberts, Department of Medicine, Charing Cross Hospital Medical School, Fulham Palace Road, London W6 8RF, UK. 